\title{
FAKTOR - FAKTOR YANG BERHUBUNGAN DENGAN STRESS KERJA PERAWAT DI RUANG ICU RS STELLA MARIS MAKASSAR
}

\author{
${ }^{1}$ Haerani \\ ${ }^{2}$ Edison Siringoringo \\ ${ }^{1}$ Departemen Keperawtan Dasar Stikes Panrita Husada Bulukumba \\ ${ }^{2}$ Departemen Keperawatan Anak dan Maternitas Stikes Panrita Husada Bulukumba
}

\author{
Alamat Korespondensi: \\ Ns.Haerani, S.Kep,M.Kep \\ Program Studi Profesi Ners \\ Sekolah Tinggi Ilmu Kesehatan Panrita Husada \\ HP: 085236933338 \\ Email:Ners_rani@yahoo.co.id
}




\begin{abstract}
ABSTRAK
Stress kerja merupakan suatu faktor penting yang perlu diperhatikan dalam meningkatkan kinerja perawat dan kualitas pencapaian tujuan dalam asuhan keperawatan.Penelitian ini bertujuan untuk mengetahui faktor - faktor yang berhubungan dengan stres kerja perawat ICU. Desain penelitian adalah cross sectional dengan jumlah sampel 30 orang perawat di ruang ICU, dimana keseluruhan anggota populasi di jadikan sampel. Pengumpulan data dengan kuesioner. Data dianalisis melalui uji Chi Square Test dengan koreksi kontinuitas atau Yates Correction. Analisis multivariat digunakan untuk melihat faktor yang paling berhubungan dengan stress kerja perawat. Hasil penelitian menunjukkan bahwa 13 orang $(43,3 \%)$ stress ringan dan 17 orang $(56,7 \%)$ stress berat. Hasil analisis bivariat variabel independen dengan dependen : Faktor intrinsik pekerjaan $(\mathrm{p}=0.001)$, Faktor ekstrinsik pekerjaan $(\mathrm{p}=0.005)$, Faktor individu $(\mathrm{p}=0.004)$. Analisis multivariat menunjukkan bahwa faktor intrinsik pekerjaan merupakan faktor yang paling berhubungan dengan stress kerja perawat ICU. Disimpulkan bahwa ada hubungan faktor instrinsik pekerjaan, faktor ekstrinsik pekerjaan, faktor individu dengan kejadian stress kerja perawat ICU. Diharapkan perbaikan faktor instrinsik pekerjaan seperti beban kerja, rutinitas kerja dan suasana lingkungan kerja dapat dijadikan program dalam mencegah terjadinya stress kerja bagi perawat ICU.
\end{abstract}

\title{
Kata Kunci : Faktor Stress Kerja, Perawat ICU
}

\begin{abstract}
Job stress is an important factor to consider in improving the performance and quality of goal achievement nurses in nursing care The aim of the research was to find the factors related to work stress of ICU nurses. The research was a cross sectional study. The sample consisted of 30 nurses of all population in ICU. The data were obtained using queitionaire and analized using chi squere test with contuinity correction or Yates Correction. The result of multivariate analysis was used to see the most dominant factor releted to work stress of ICU nurses. The result of the research indicate that there are 13 (43.3\%) people having a slight stress and 17 $(56.7 \%)$ people having a severe stress. The result of bivariate analysis between independent variable and dependent variable indicate job intrinsic factor $(p=0.001)$, job extrinsic factor $(p=0.005)$, and individual factor $(p=0.004)$. the analysis of multivariate analysis indicate that intrinsic factor is the most related factor with work stress of ICU nurses. It is concluded that there is correlation between work ontrinsic factor, work extrinsic factor, individual factor and work stress ICU nurses. It is expected that the improvement of job intrinsic factor such as work load, work rutinity, and work invorenment situation could become the program in avoiding the occurrence of work stress of ICU nurses.
\end{abstract}

Key Words : Job Stress, ICU Nurses 


\section{PENDAHULUAN}

Stress kerja adalah kondisi yang muncul dari interaksi antara menusia dan pekerjaan serta dikarakterisasikan oleh perubahan manusia yang memaksa mereka untuk menyimpang dari fungsi normal mereka (Luthans, F. 2006) Tugas dan tanggung jawab perawat bukan hal yang ringan untuk dipikul, disatu sisi perawat bertanggungjawab terhadap tugas fisik, administratif, dari instansi tempat ia bekerja, menghadapi kecemasan, keluhan dan mekanisme pertahanan diri pasien yang muncul pada pasien akibat sakitnya, ketegangan, kejenuhan dalam menghadapi pasien dalam kondisi yang menderita sakit kritis atau keadaan terminal, di sisi lain ia dituntut untuk selalu tampil sebagai profil perawat yang baik oleh pasiennya (Danang, P. 2009). Berbagai situasi dan tuntutan kerja yang dialami dapat menjadi sumber potensial terjadinya Stress (Golizeck, A. 2005)

Karakteristik perawat ICU, yaitu dituntut memiliki tingkat pengetahuan dan keterampilan yang lebih baik daripada perawat lain dalam menangani pasien yang memiliki kondisi kritis. Perawat ICU juga rentan mengalami Post Traumatic Stress Disorder (PTSD) dibandingkan dengan perawat umum (Mealer, M. L. 2007). Berdasarkan penelitian Mealer didapatkan hasil bahwa dari 121 responden dari perawat umum terdapat 17 responden yang mengalami PTSD (14\%) sedangkan dari 230 perawat ICU, terdapat 54 responden yang mengalami PTSD (24\%),

Pelayanan di ICU dapat memberi dampak pada perawat berupa kejenuhan dalam pemberian asuhan keperawatan pada pasien dengan keadaan terminal yang lama, bahkan sampai berbulan-bulan tetapi tidak mengalami perbaikan kondisi kesehatan. Hal ini dapat menyebabkan kelelahan emosional yang mengarah terjadinya burnout dibuktikan dari penelitian yang dilakukan oleh Meltzer, L. S. et al., (2004) dari 60 perawat ICU pada dua buah rumah sakit di California Selatan. Ditemukan hubungan yang positif dan signifikan dari uji korelasi product moment Pearson $(r=0317, p=0.05)$.

Kejadian stress kerja yang dialami oleh beberapa perawat yang bekerja di ruangan perawatan ICU, setelah diidentifikasi diperoleh bahwa sebagian perawat sebanyak 17 perawat $(56,7 \%)$ mengalami stress kerja berat, $46,7 \%$ memiliki tingkat kepuasan kerja yang kurang dengan 20 perawat $(66,7 \%)$ dengan kinerja buruk. Stres kerja yang dialami perawat dapat membantu dalam meningkatkan kinerja dan juga dapat menyebabkan menurunnya kinerja. Bila tidak ada stress, tantangan-tantangan kerja tidak ada sehingga prestasi kecenderung rendah. Bila stress menjadi terlalu besar, prestasi kerja akan menurun. Penilaian 
kinerja merupakan suatu upaya dalam mengevaluasi hasil kerja seseorang dengan membandingkannya terhadap standar pelaksanaan yang diharapkan.

Melalui wawancara dengan kepala ruangan ICU RS. Stella Maris Makassar, diperoleh informasi bahwa perawat yang bekerja diruang ICU RS. Stella Maris sering mengeluh adanya stres terutama bagi perawat baru. Pemberlakuan rotasi perawat keruang ICU pun pada sebagian perawat mengeluhkan adanya stressor dan beban kerja yang tinggi yang dibuktikan dengan didapatinya keadaan dimana perawat yang enggan untuk ditempatkan di ruang ICU dan keinginan untuk dipindahkan keruangan lain.

Tujuan dalam penelitian ini adalah diketahuinya faktor - faktor yang berhubungan dengan stres kerja perawat $d$ iruang ICU RS. Stella Maris Makassar.

\section{METODE}

Penelitian ini dilakukan di RSU Stella Maris Makassar Sulawesi Selatan. Jenis penelitian yang digunakan adalah deskriptif analitik dengan menggunakan desain cross sectional Studi

Populasi dalam penelitian ini adalah seluruh perawat pelaksana di ruang ICU RS. Stella Maris Makassar. Sampel berjumlah 30 perawat yang ditentukan dengan menggunakan tehnik total sampling yang sebelumnya telah menandatangani informed consent yang telah dikeluarkan oleh Komite Etik Fakultas Kedokteran Universitas Hasanuddin.

Pengumpulan data dilakukan dengan menggunakan kuesioner. Data faktor stress kerja ( Faktor Instrinsik, faktor Ekstrinsik, faktor individu) diukur dengan menggunakan daftar kuesioner. Data gejala stress kerja diukur dengan mengguakan daftar pertanyaan kuesoner juga.

Seluruh data, baik data faktor stress kerja maupun gejala stress kerja, di olah dengan menggunakan SPSS for windows 16.00. Untuk menilai hubungan faktor stress kerja dengan kejadian stress kerja perawat digunakan analisis multivariate "uji regresi logistik ganda"

\section{HASIL}

Tabel 1 menunjukkan karakteristik perawat yang menjadi sampel dalam penelitian ini. Sebagian besar perawat berjenis kelamin perempuan sebanyak 19 orang $(63,3 \%)$. Berdasarkan kelompok umur menunjukkan bahwa distribusi umur responden dengan persentase tertinggi adalah pada kelompok umur 21 - 27 tahun yaitu sebanyak 20 orang $(66,7 \%)$. Berdasarkan pendidikan menunjukkan bahwa sebagian besar perawat dengan pendidikan D3 yaitu sebanyak 24 orang 
$(80 \%)$. Berdasarkan status pernikahan menunjukkan bahwa responden terbanyak adalah yang belum menikah yaitu sebanyak 16 orang $(53,3 \%)$. Berdasarkan Lama Bekerja menunjukkan bahwa responden tertinggi adalah perawat yang bekerja sudah 1-7 tahun yaitu sebanyak 22 orang $(73,3 \%)$.

Tabel 2 memperlihatkan distribusi beban kerja berat dengan 16 orang $(53,3 \%)$. rutinitas kerja monoton dan membosankan 19 orang (63,3\%). suasana lingkungan kerja menunjang dan tidak menunjang dengan 15 orang (50\%). hubungan interpersonal perawat dengan dokter, 16 orang $(53,3 \%)$. Pengembangan karir buruk 19 orang $(63,3 \%)$. peran dalam organisasi yang baik 20 orang $(66,7 \%)$. pengawasan atasan yang buruk 20 orang $(66,7 \%)$. tidak ada masalah keluarga anyak 16 orang $(53,3 \%)$. Memiliki masalah ekonomi 20 orang $(66,7 \%)$. Tipe kepribadian B dengan 20 orang (66,7\%).

Pada table 3 diperlihatkan ada hubungan antara faktor intrinsik pekerjaan faktor ekstrinsik pekerjaan, faktor individu dengan stres kerja perawat $(\mathrm{P}<0.05)$

Table 4 memperlihatkan bahwa tidak semua variabel memiliki hubungan bermakna secara statistik. Ditetapkan bahwa hanya faktor intrinsic pekerjaan dan faktor individu di luar pekerjaan yang memiliki hubungan dengan stres kerja perawat dan dari nilai wald didapatkan faktor intrinsic pekerjaan merupakan faktor paling dominan mempengaruhi stres kerja perawat. $($ wald $=6.752 ; \mathrm{p}=0,009)$

\section{PEMBAHASAN}

Penelitian ini memperlihatkan bahwa ada hubungan faktor penyebab stress kerja dengan kejadian stress kerja yaitu Beban kerja, rutinitas kerja, suasana lingkungan kerja hubungan interpersonal perawat, pengembangan karir, peran dalam organisasi, pengawasan atasan, masalah keluarga, masalah ekonomi, dan tipe kepribadian.

Beban kerja merupakan salah satu tuntutan yang menjadi stressor dalam pekerjaan dan beban kerja berlebih/beban kerja terlalu sedikit merupakan pembangkit terjadinya stress (Munandar, A. S. 2008)

Hasil penelitian menunjukkan bahwa beban kerja perawat yang berat mengalami stress kerja yang berat. Dari data tersebut menunjukan bahwa semakin berat persepsi beban kerja, maka semakin tinggi tingkat stress yang dialami. Hal ini terbukti dari hasil penelitian ini bahwa dari $53.3 \%$ perawat yang mengalami beban kerja berat, $76.5 \%$ mengalami stress berat. Hasil penelitian ini sejalan dengan yang dikatakan prihatini, Beban kerja yang berlebih pada perawat dapat memicu timbulnya stres dan burnout. Perawat yang mengalami stres dan burn out 
memungkinkan mereka untuk tidak dapat menampilkan performa secara efektif dan efisien dikarenakan kemampuan fisik dan kognitif mereka menjadiberkurang. (Carayon P, et al., 2010).

Rutinitas kerja berat sebesar $63.3 \%$ dan sebesar $88,2 \%$ mengalami stress kerja berat. Faktor penyebab perawat mengalami stres di Ruangan ICU diantaranya disebabkan oleh adanya kejenuhan. Sebab kejenuhan antara lain pekerjaan rutin yang diulang-ulang dan setiap langkah harus ditulis yang dipersepsikan sebagai pekerjaan yang monoton dan membosankan.( Hudak, C. M. et al., 2010)

Suasana lingkungan kerja yang tidak menunjang sebesar $50 \%$ dan sebesar $76,5 \%$ mengalami stress kerja berat. Tingginya stress kerja tersebut disebabkan oleh persepsi perawat terhadap besarnya tanggung jawab perawatan pasien kritis dimana perawat dihadapkan tidak hanya pada kondisi pasien yang kritis tetapi juga kebutuhan akan mutu dan teknik perawatan yang baik (Ling, L. H. et al., 2005).

Hubungan interpersonal perawat yang buruk sebesar $46.7 \%$ dan sebesar $70,6 \%$ mengalami stress kerja berat. Hubungan interpersonal yang buruk (Adanya konflik interpersonal dengan dokter, rekan kerja, atasan, pasien dan keluarganya) merupakan salah satu penyebab terjadinya stress kerja pada perawat (Ling, L. H. et al., 2005). Perkembangan karir yang buruk sebesar $63.3 \%$ dan sebesar $82,4 \%$ mengalami stress kerja berat.

Pengembangan karir merupakan pembangkit stres yang potensial yang mencakup ketidakpastian pekerjaan, tidak adanya pengahargaan, promosi yang berlebih atau promosi yang kurang Semakin buruk perkembangan karir, dapat meningkatkan tingkat stress kerja perawat tersebut. Sebaliknya semakin baik perkembangan karir perawat semakin menurunkan tingkat stress perawat. Pengembangan karir (promosi) sendiri dapat merupakan sumber stress, jika peristiwa tersebut dirasakan sebagai perubahan drastis yang mendadak, misalnya jika pekerja kurang dipersiapkan untuk promosi, ketidak pastian pekerjaan, promosi yang berlebihdan promosi yang kurang.( Munandar, A. S. 2008)

Peran dalam organisasi yang buruk sebesar $33.3 \%$ dan sebesar $52,9 \%$ mengalami stress kerja berat. Setiap tenaga kerja bekerja sesuai dengan perannya dalam organisasi, artinya setiap tenaga kerja mempunyai kelompok tugasnya yang harus ia lakukan sesuai aturan - aturan yang ada dan sesuai . dengan yang diharapkan oleh atasannya. Setiap tenaga kerja bekerja sesuai dengan perannya dalam organisasi artinya setiap tenaga kerja mempunyai kelompok tugasnya yang 
harus dilakukan sesuai dengan aturanaturan yang ada dan sesuai dengan yang diharapkan oleh atasannya, namun demikian tenaga kerja tidak selalu berhasil untuk memainkan perannya tanpa menimbulkan masalah. Kurang baiknya fungsi peran merupakan pembangkit stres yang meliputi konflik peran dan ketidak jelasan kerja. (Ling, L. H. et al., 2005)

Pengawasan atasan yang buruk sebesar $66.7 \%$ dan sebesar 88,2\% mengalami stress kerja berat. Tidak adanya atau kurangnya Kontrol dalam tugas (supervisi) dari atasan (khususnya pengawasan dari supervisor, kepala ruangan atau pengawasan dari manajemen keperawatan yang lebih tinggi) dapat menjadi salah satu penyebab dan memicu terjadinya stress kerja bagi perawat (NIOSH, 2008).

Perawat yang memiliki masalah keluarga cenderung mengalami stress kerja yang berat yaitu sebesar 70,6\%. Setiap individu selalu mengharapkan peristiwaperistiwa kehidupan yang dialaminya sesuai dengan keinginannya. Penilaian kognitif dalam menghadapi stress melibatkan pengalaman individu di masa lalu menggunakan pengalamanpengalaman yang memiliki makna mendalam bagi individu tersebut. Secara psikologis, peristiwa kehidupan dapat mengganggu perawat ICU yaitu antara lain karena peristiwa tidak menyenangkan yang berhubungan dengan rumah tangga (keluarga) (Sarafino, E. P. 2010).

Perawat yang memiliki masalah ekonomi cenderung mengalami stress kerja yang berat yaitu sebesar $88,2 \%$. Masalah ekonomi perawat diciptakan oleh perawat yang tidak dapat mengelola sumber daya keuangan mereka merupakan satu contoh kesulitan pribadi yang dapat menciptakan stres bagi perawat dan mengalihkan perhatian mereka dalam bekerja.

Berdasarkan hasil penelitian dari faktor tipe kepribadian menunjukkan yang memiliki tipe kepribadian A yakni karakter perawat yang memiliki paksaan untuk bekerja berlebih, selalu bergelut dengan batas waktu, dan sering menelantarkan aspek asuhan keperawatan cenderung mengalami stress kerja yang ringan yaitu sebesar $46,2 \%$. Sebaliknya perawat yang memiliki tipe kepribadian B cenderung mengalami stress kerja yang berat yaitu sebesar $76,5 \%$.

Hubungan tipe kepribadian dengan stres kerja menggambarkan bahwa 10,6\% dari tipe kepribadian memberikan pengaruh terhadap terjadinya stress kerja terutama pada tipe kepribadian A, karena tipe ini memiliki perilaku dan sikap mental dengan cirri-ciri yang rentan terhadap stress (Danang, P. 2006).

Sesuai hasil analisis multivariate didapati bahwa variable faktor intrinsik pekerjaan adalah merupakan faktor yang 
paling berhubungan dengan stress kerja perawat. Hal ini sesuai dengan hasil penelitian Ling, L. H. et al., (2005) mengidentifikasi faktor penyebab terjadinya stres kerja di ruangan ICU meliputi prosedur yang dilakukan secara rutin diruangan ICU, kurangnya motivasi perawat dan kurangnya staf perawat yang kompoten dan tantangan pasien dengan kondisi emergensi dan kasus pasien dengan henti jantung paru. Hal tersebut sejalan dengan bukti penelitian Hudak, C. M et al., (2010) yang mengidentifikasi faktor penyebab terjadinya stres kerja di ruangan ICU salah satunya akibat kejenuhan. Sebab kejenuhan antara lain: pekerjaan rutin yang diulang-ulang, setiap langkah harus ditulis, perpindahan perawat dari tempat lain, situasi krisis akut yang sering terjadi dan lain-lain.

\section{KESIMPULAN DAN SARAN}

Kami menyimpulkan bahwa terdapat hubungan faktor intrinsik pekerjaan, ekstrinsik pekerjaan, faktor individu dengan stress kerja perawat dan faktor intrinsik pekerjaan merupakan variable yang paling berhubungan dengan stress kerja perawat. Upaya untuk mencegah stress kerja dapat dilakukan melalui olah raga, tehnik relaksasi atau refresing pribadi, meningkatkan kualitas dan kuantitas komunikasi dengan atasan, meningkatkan pengetahuan formal melalui jenjang pendidikan lebih lanjut ataupun melalui pelatihan.

\section{DAFTAR PUSTAKA}

Carayon, P. et al., (2010). Patient Safety and Quality: An Evidence-Based Handbook for Nurses, Philadelphia: F.A Davis Company

Danang, P. (2009). Hubungan Stress Kerja dengan Adaptasi Pada Perawat DiInstalasi Gawat Darurat RSUD Pandan Arang. (Tesis), Jakarta: Universitas Indonesia

Hudak, C. M et al., B. M. (2010) Keperawatan kritis: Pendekatan holistik. Volume 1 (Ed. 6) (M. Ester, Editor) (Asih, Penerjemah). Jakarta: EGC.

Ling, L. H. et al., (2005). Perception of stress in an intensive care unit setting among working in intensive care unit and general ward. Surgical Intensive Care Unit Journal, 14(3):195-202.

Golizeck, A. (2005)::60 Second Manajemen Stress. Jakarta: Buana Ilmu popular.

Luthans, F. (2006). Perilaku organisasi. Edisi: 10. Yogyakarta: Andi.

Mealer, M. L., et al., (2007). Increased Prevalence of Post-traumatic Stress Disorder Symptoms in Critical Care Nurses, American Journal of Respiratory \& Critical Care Medicine, 175(1), 693-697.

Meltzer, L. S, et al., (2004) Critical care nurses perceptions of futile care and its effect on burnout, American journal of critical care 13(1) 202-208

Munandar, A. S. (2008). Psikologi Industri dan Organisasi. Jakarta: UI-Press

NIOSH. (2008). Exposure to Stress Occupational Hazard in Hospital. NIOSH.

Sarafino, E. P. (2010). Health Psychology. Singapore; john Wiley \& Sons, Inc. 
Table 1. Karakteristik Perawat Menurut Jenis kelamin, Umur, Pendidikan, Status Pernikahan, Lama bekerja

\begin{tabular}{|c|c|c|}
\hline Variabel & $\mathbf{n}$ & $\%$ \\
\hline \multicolumn{3}{|l|}{ Jenis Kelamin } \\
\hline Laki-laki & 6 & 24.0 \\
\hline Perempuan & 24 & 80.0 \\
\hline \multicolumn{3}{|l|}{ Umur } \\
\hline $21-27$ & 20 & 66.7 \\
\hline $28-34$ & 8 & 26.7 \\
\hline $35-41$ & 1 & 3.3 \\
\hline $42-48$ & 1 & 3.3 \\
\hline \multicolumn{3}{|c|}{ Pendidikan Perawat } \\
\hline SPK & 4 & 13.3 \\
\hline DIII Keperawatan & 24 & 80.0 \\
\hline S1 Keperawatan & 2 & 6.7 \\
\hline \multicolumn{3}{|l|}{ Status Pernikahan } \\
\hline Menikah & 14 & 46.7 \\
\hline Belum Menikah & 16 & 53.3 \\
\hline \multicolumn{3}{|l|}{ Lama Bekerja } \\
\hline $1-7$ & 22 & 73.3 \\
\hline $8-14$ & 5 & 16.7 \\
\hline $15-21$ & 2 & 6.7 \\
\hline $22-28$ & 1 & 3.3 \\
\hline Total & 30 & 100.0 \\
\hline
\end{tabular}


Table 2. Distribusi Perawat Menurut beban kerja, rutinitas kerja, suasana lingkungan kerja, hubungan interpersonal perawat, pengembangan karir, peran dalam organisasi, pengawasan atasan, masalah keluarga, masalah ekonomi, tipe kepribadian

\begin{tabular}{|c|c|c|c|}
\hline Variabel & kriteria & frekwensi & $\%$ \\
\hline \multicolumn{4}{|l|}{ Faktor Intrinsik pekerjaan: } \\
\hline \multirow[t]{2}{*}{ - Beban kerja } & Ringan & 14 & 46,7 \\
\hline & Berat & 16 & 53,3 \\
\hline Total & & 30 & 100.0 \\
\hline \multirow[t]{3}{*}{ - Rutinitas kerja } & Tidak monoton & & \\
\hline & $\begin{array}{l}\text { dan tidak } \\
\text { membosankan }\end{array}$ & 11 & 36,7 \\
\hline & $\begin{array}{l}\text { Monoton dan } \\
\text { membosankan }\end{array}$ & 19 & 63,3 \\
\hline Total & & 30 & 100.0 \\
\hline \multirow[t]{2}{*}{ - Suasana lingkungan kerja } & Menunjang & 15 & 50,0 \\
\hline & Tidak menunjang & 15 & 50,0 \\
\hline Total & & 30 & 100.0 \\
\hline \multicolumn{4}{|l|}{ Faktor Ekstrinsik Pekerjaan: } \\
\hline \multirow[t]{2}{*}{ - Hubungan interpersonal } & Baik & 16 & 53,3 \\
\hline & Buruk & 14 & 46,7 \\
\hline \multirow{3}{*}{$\begin{array}{c}\text { Total } \\
\text { - } \quad \text { Pengembangan karir }\end{array}$} & & 30 & 100.0 \\
\hline & Baik & 11 & 36,7 \\
\hline & Buruk & 19 & 63,3 \\
\hline Total & & 30 & 100.0 \\
\hline \multirow[t]{2}{*}{ - Peran dalam organisasi } & Baik & 20 & 66,7 \\
\hline & Buruk & 10 & 33,3 \\
\hline Total & & 30 & 100.0 \\
\hline \multirow[t]{2}{*}{ - Pengawasan atasan } & Baik & 10 & 33,3 \\
\hline & Buruk & 20 & 66,7 \\
\hline Total & & 30 & 100.0 \\
\hline
\end{tabular}

Faktor individu diluar pekerjaan:

- Masalah keluarga

Tidak ada

masalah

16

53,3

Ada masalah

$14 \quad 46,7$

Total

- Masalah ekonomi

Tidak ada

30

100.0

masalah

10

33,3

Ada masalah

66,7

Total

30

100.0

- Tipe kepribadian

Tipe A

10

33,3

Tipe B

$20 \quad 66,7$

Total

30

100.0


Table 3. Hubungan Faktor Intrinsik, Ekstrinsik, Individu Pekerjaan, Dengan Stres Kerja

\begin{tabular}{|c|c|c|c|c|c|c|c|c|c|}
\hline \multirow[t]{3}{*}{ Variabel } & \multirow[t]{3}{*}{ Kriteria } & \multicolumn{4}{|c|}{ Stress kerja } & \multirow[t]{3}{*}{ Total } & \multirow[t]{3}{*}{$\%$} & \multirow{3}{*}{$\begin{array}{c}\text { P. } \\
\text { Value }\end{array}$} & \multirow[t]{3}{*}{ O.R } \\
\hline & & \multicolumn{2}{|c|}{ Ringan } & \multicolumn{2}{|c|}{ Berat } & & & & \\
\hline & & $\mathrm{n}$ & $\%$ & $\mathbf{n}$ & $\%$ & & & & \\
\hline \multirow{2}{*}{$\begin{array}{l}\text { Faktor } \\
\text { instrinsik }\end{array}$} & Baik & 1 & 7,7 & 13 & 76,5 & 14 & 46,7 & \multirow[t]{2}{*}{0.001} & \multirow[t]{2}{*}{0.026} \\
\hline & Buruk & 12 & 92,3 & 4 & 23,5 & 16 & 53,3 & & \\
\hline \multirow[t]{2}{*}{ total } & & 13 & 100 & 17 & 100 & 30 & 100 & \multirow[b]{4}{*}{0,005} & \multirow[b]{4}{*}{22,0} \\
\hline & & 12 & 92,3 & 6 & 35,3 & 18 & 60,0 & & \\
\hline \multirow{2}{*}{$\begin{array}{l}\text { Faktor } \\
\text { ekstrinsik }\end{array}$} & Baik & & & & & & & & \\
\hline & Buruk & 1 & 7,7 & 11 & 64,7 & 12 & 40,0 & & \\
\hline \multirow[t]{2}{*}{ total } & & 13 & 100 & 17 & 100 & 30 & 100 & \multirow[b]{3}{*}{0,004} & \multirow[b]{3}{*}{15,5} \\
\hline & \multirow[b]{2}{*}{ Baik } & 10 & 76,9 & 3 & 17,6 & 13 & 43,3 & & \\
\hline $\begin{array}{l}\text { Faktor } \\
\text { Individu }\end{array}$ & & 3 & 23,1 & 14 & 82,4 & 17 & 56,7 & & \\
\hline Total & & 13 & 100 & 17 & 100 & 30 & 100 & & \\
\hline
\end{tabular}

Table 4 Hasil Analisis Regresi Logistik Berganda Stres Kerja Perawat

\begin{tabular}{lcc}
\hline \multicolumn{1}{c}{ Variabel } & Wald & P \\
\hline Faktor Intrinsik & 6.751 & 0.009 \\
Faktor Individu & 4.605 & 0.032 \\
Constan & 0.608 & 0.435 \\
\hline
\end{tabular}

